\title{
Analysis of Land Use and Land Cover Changes and Evaluation of Natural Generation and Potential Restoration Areas in the Mexican Huasteca Region
}

\author{
Carmelo Peralta-Rivero ${ }^{1}$, Carlos Contreras-Servín ${ }^{1}$, María G. Galindo-Mendoza ${ }^{1}$, \\ Jean-François Mas Caussel ${ }^{2}$, Marcos Algara-Siller ${ }^{3}$ \\ ${ }^{1}$ Multidisciplinary Graduate Programme in Environmental Sciences, Autonomous University of San \\ Luis/Coordination for Innovation and the Application of Science and Technology, San Luis Potosi, Mexico \\ ${ }^{2}$ Institute of Geography, National Autonomous University of Mexico, Morelia, Mexico \\ ${ }^{3}$ Multidisciplinary Graduate Programme in Environmental Sciences, Faculty of Engineering, Environmental \\ Engineering, Autonomous University of San Luis, San Luis Potosi, Mexico \\ Email: peralta.carmelo@gmail.com
}

Received November 21 $1^{\text {st }}, 2013$; revised December $28^{\text {th }}$, 2013; accepted January $19^{\text {th }}, 2014$

\begin{abstract}
Copyright (C 2014 Carmelo Peralta-Rivero et al. This is an open access article distributed under the Creative Commons Attribution License, which permits unrestricted use, distribution, and reproduction in any medium, provided the original work is properly cited. In accordance of the Creative Commons Attribution License all Copyrights (C) 2014 are reserved for SCIRP and the owner of the intellectual property Carmelo Peralta-Rivero et al. All Copyright $\odot 2014$ are guarded by law and by SCIRP as a guardian.
\end{abstract}

\begin{abstract}
This study aims to analyze temporal changes in land use and land cover change (LUCC) as well as identify areas for natural regeneration and potential areas for forest restoration in the Huasteca region for the period from 1976 to 2007. Changes were quantified in numbers and, additionally, cartography was used to identify and map the main affected areas. Different models based on Geographic Information Systems (GIS) demonstrated that LUCC have occurred on an area of $11718.82 \mathrm{~km}^{2}$, representing $17.84 \%$ of the region's surface. Agriculture and the growth of pasture could be identified as the main human-induced activities that have led to landscape modification. In addition, forest cover is affected by a deforestation rate which is higher than the national average. Further important changes include a change from natural land cover to non-original land cover, affecting an area of $4911.88 \mathrm{~km}^{2}$ in the period from 1976-1993, and an area of $1892.5 \mathrm{~km}^{2}$ in the period from 1993-2002. Smaller changes could be observed for the period from 1993-2002 with an affected area of $1029.78 \mathrm{~km}^{2}$. At the same time, a natural regeneration from nonoriginal to original land cover took place from 1976-1993 on an area of $1318.68 \mathrm{~km}^{2}$, and also on an area of $974.18 \mathrm{~km}^{2}$ between 1993 an 2002. The surface that underwent a natural regeneration of forest cover made up $1932.07 \mathrm{~km}^{2}$. At the same time, an area of $5739.29 \mathrm{~km}^{2}$ for potential forest restoration was identified. Drawing on GIS methods and techniques, the development of thematic maps for land use, land use and land cover changes for the years of analysis (1976-1993-2002-2007) proved to be very adequate for the evaluation and analysis of the land cover and land use change, in particular with regard to the decrease of natural vegetation cover.
\end{abstract}

Keywords: Land User; Land Cover; Natural Regeneration; Forest Restoration; LUCC; GIS; Temporal Analysis; Huasteca

\section{Introduction}

In the twentieth century, human-induced activities substantially changed the biophysical surface of the earth (Ramankutty et al., 2006), due to the fact that the human population gained possession of between $20 \%$ and $40 \%$ of primary net productivity of the planet. At the same time, changed consumption patterns based on the development of economic activities had a direct influence on the transformation of ecosystems (Vitouseck et al., 1986; Bassols, 1993; Oliva et al., 2010). This has provoked the generation of differentiated spatial patterns of land use change which, generally, are reflected in the loss of areas with natural vegetation such as temperate or tropical forests (López-Blanco, 2005).

This ambition to convert forests and rain forests in grounds for livestock production and agriculture has caused annual deforestation rates of up to $2 \%$ in the world's rain forests (Dirzo \& García, 1995; Castillo-Santiago et al., 2007; Pacheco et al., 2009). In the case of the Mexican Republic, 52\% of the country's total surface of $1,945,748 \mathrm{~km}^{2}$ was covered by forests, rainforests and large areas of scrublands with tree vegetation that reached a height of up to 3 meters.

The National Forest Inventory for the year 2000 registered a loss of $36 \%$ with regard to forest and rainforest ecosystems (Ricker, 2010). According to Velazquéz et al., (2002), deforestation rates in Mexico vary between $-0.25 \%$ and $-1.02 \%$ for the period from 1976 to 2000, indicating a loss of $0.25 \%$ and $1.02 \%$ of forest cover per year. Land use mapping data from the National Institute for Statistics and Geography until the year 2007 indicates that in the year 2007, forest areas in Mexico 
were only made up approximately 64,785,000 hectares of forest and 20,128,000 hectares of other forest areas (FAO/FRA, 2010).

Especially in the Huasteca Region in Mexico, forest cover has been modified in various ways as a result of human-induced activities. The most important alteration can be observed with regard to rainforests and forest (Quinteros, 2012). Capitalist modernization has accelerated and deepened these changes since the age of industrialization provoked the increase of livestock herding, the demand for wood and the need for woodderived products (Aguilar-Robledo, 2001).

Despite this loss of forest cover in the past, there is little quantifiable information on the deforestation rate and other changes in land use and land cover that have occurred in this important Mexican region, which has traditionally been famous for great natural potential due to forest resources.

Hence, the timely and precise evaluation of patterns pertaining to land use and land use change allows understanding how regeneration, succession and degradation processes work in woodland ecosystem (Márquez-Linares et al., 2005). At the same time, this study will contribute to the development of forest management, conservation and restoration strategies in an area affected by human-induced activities (Zepeda et al., 2012b).

Based on the previous discussion, this study aims to evaluate the changes in land use and land cover in the Huasteca region in order to quantify and map the main affected areas as well as generate information on forest resources and decision-making for a sound forest management and the restoration of forest cover.

\section{Study Area}

The Huasteca region is divided into different political and administrative entities, each of which is named according to the state of the Mexican Republic to which it belongs. This is how the Huasteca is constituted by the Huasteca "hidalguense, potosina, tamaulipeca, veracruzana, poblana y queretana” (Figure 1). The region is located between $22^{\circ} 16^{\prime} 00^{\prime \prime}$ Northern Latitude and $98^{\circ} 30^{\prime} 00^{\prime \prime}$ Western Longitude; covering approximatelty 65675.85 $\mathrm{km}^{2}$ with a population of about $3,064,711$ habitants (CONABIO, 2012).

Within the region, different biophysical climate and vegetation factors come together with human-induced activities such as agriculture and livestock production, which may have an important impact on the transformation of ecosystems (Algara, 2009).

\section{Methodology}

\section{Preparation of the Data Base}

The methodological approach was based on the use of a Geographical Information System, which allowed analyzing changes in land use and land cover with a reasonable degree of effectiveness (Treitz \& Rogan, 2004; Berberoglu \& Akin, 2009). This method made it possible to collect, to structure and to analyze important spatial information for the management of tropical areas such as the Huasteca region (Green et al., 1996; Klemas, 2001).

Many research projects on large areas use cartography from official sources (Velázquez et al., 2002; Rosete-Vergés et al., 2009; Miranda-Aragón et al., 2013), being also the case of the
Huasteca Region. Accordingly, the data base for land use and vegetation was used corresponding to series I $\left(t_{1}\right)(1976)$, series II $\left(t_{2}\right)$ (1993), series III $\left(t_{3}\right)(2002)$, and series IV $\left(t_{4}\right)$ (2007) on a scale of 1:250,000, provided by the National Institute for Statistics and Geography (INEGI) which had generated and carried out a process of data validation. In order to obtain the data base for the study area, maps on land use and vegetation were merged and projected on the coordinate system UTM WGS-84 of the area 14 North, in order to guarantee a better overlap of polygons, and finally be able to be able to extract the study area.

Finally, classes of land cover and land use were standardized, and the following classes were established: agriculture, water, urban areas, forest, scrubland, other types of vegetation, grassland, rainforest, without vegetation and secondary vegetation (Figure 2) (Appendix 1).

Likewise, the different standardized classes were reclassified as natural covers, non original covers, water and urban areas with the aim to analyze the effect of human-induced activities on the land use and land cover in the region (Weckmüller et al., 2011; Peralta et al., 2013) (Figure 2) (Appendix 1).

\section{Analysis of Processes of Land Use and Land Cover Changes, Natural Regeneration and Restoration Areas}

In order to obtain statistical data and maps on land use andland cover changes standardized and cartography sources were superimposed with reclassified cartography sources from the series $t_{1}, t_{2}, t_{3}$ and $t_{4}$.

This part of the analysis allowed generating a reliable mapping tool which expressed the magnitude as well as the spatial distribution of land cover and land use change dynamics in the Huasteca region.

In order to describe the dynamics of change in the forest cover, a "deforestation process" model was developed, based on which change rates were calculated according to the equation introduced by the FAO (1996) (Equation (1)). This rate expresses change in terms of the percentage of the surface at the beginning of each year. For each of the other standardized classes, the same procedure was used, in a way that the results reflect all transitions regarding land cover and land use.

$$
\delta_{n}=\left(\frac{S_{2}}{S_{1}}\right)^{1 / n}-1
$$

where $\delta$ is the change rate (in order to express percentage, it has to be multiplied by 100 );

$S_{1}$ is the surface on the first date 1 ;

$S_{2}$ is the surface on the second date 2;

$n$ is the number of years between the two points of time.

Covers that were affected by systematic transitions were distinguished from those where change happened randomly. Dominant marks of change and indications for change were identified as well as gross gains and losses, with the aim to obtain the total change in the respective categories (Pontius et al., 2004). To this end, a cross-tabulation or change matrix was developed by crossing the maps created at a specific time (time 1 and time 2). In the said matrix, the rows represent the categories of the map in time $1(T 1)$ and the columns represent the categories of the map in time 2 (T2). In addition, another column is added in order to represent the deforestation rate or land use and land 


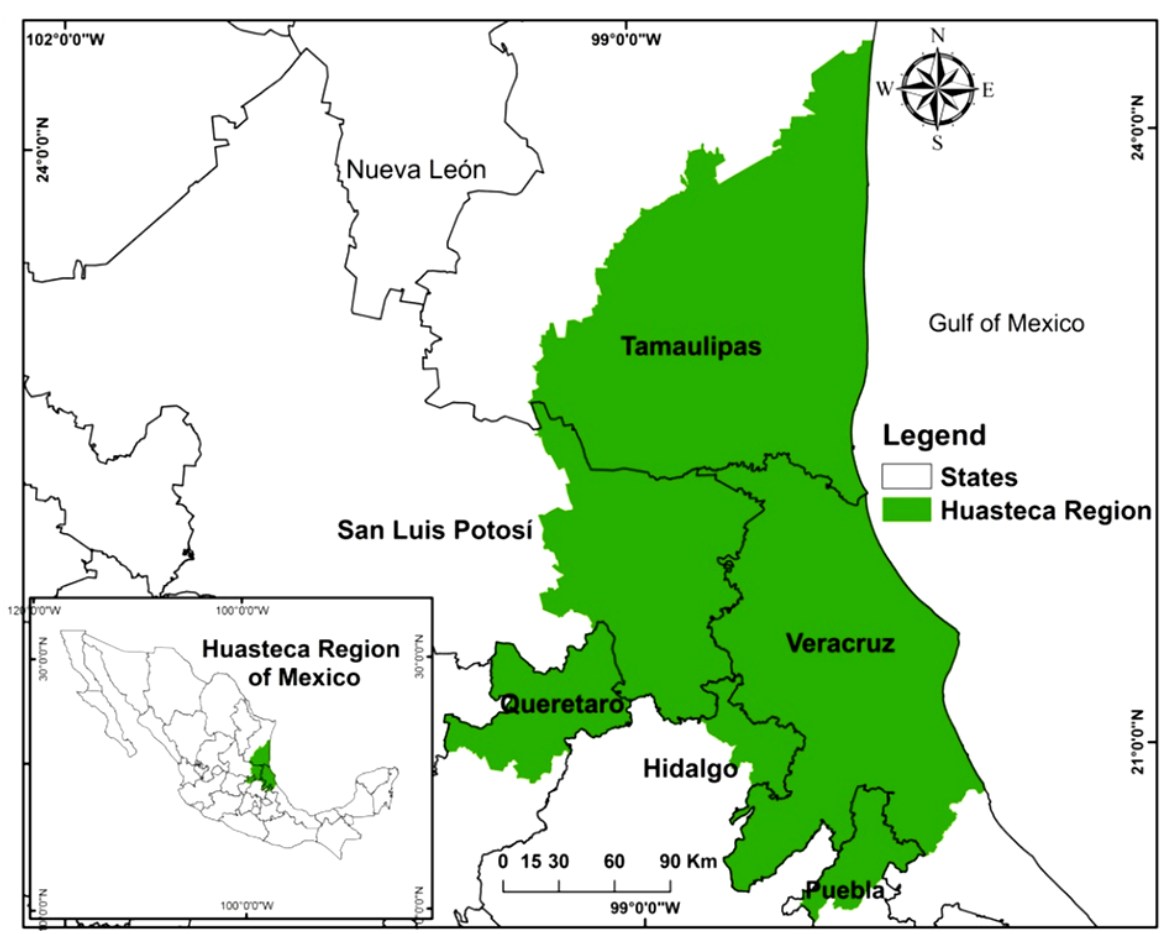

Figure 1.

Map of the study area.

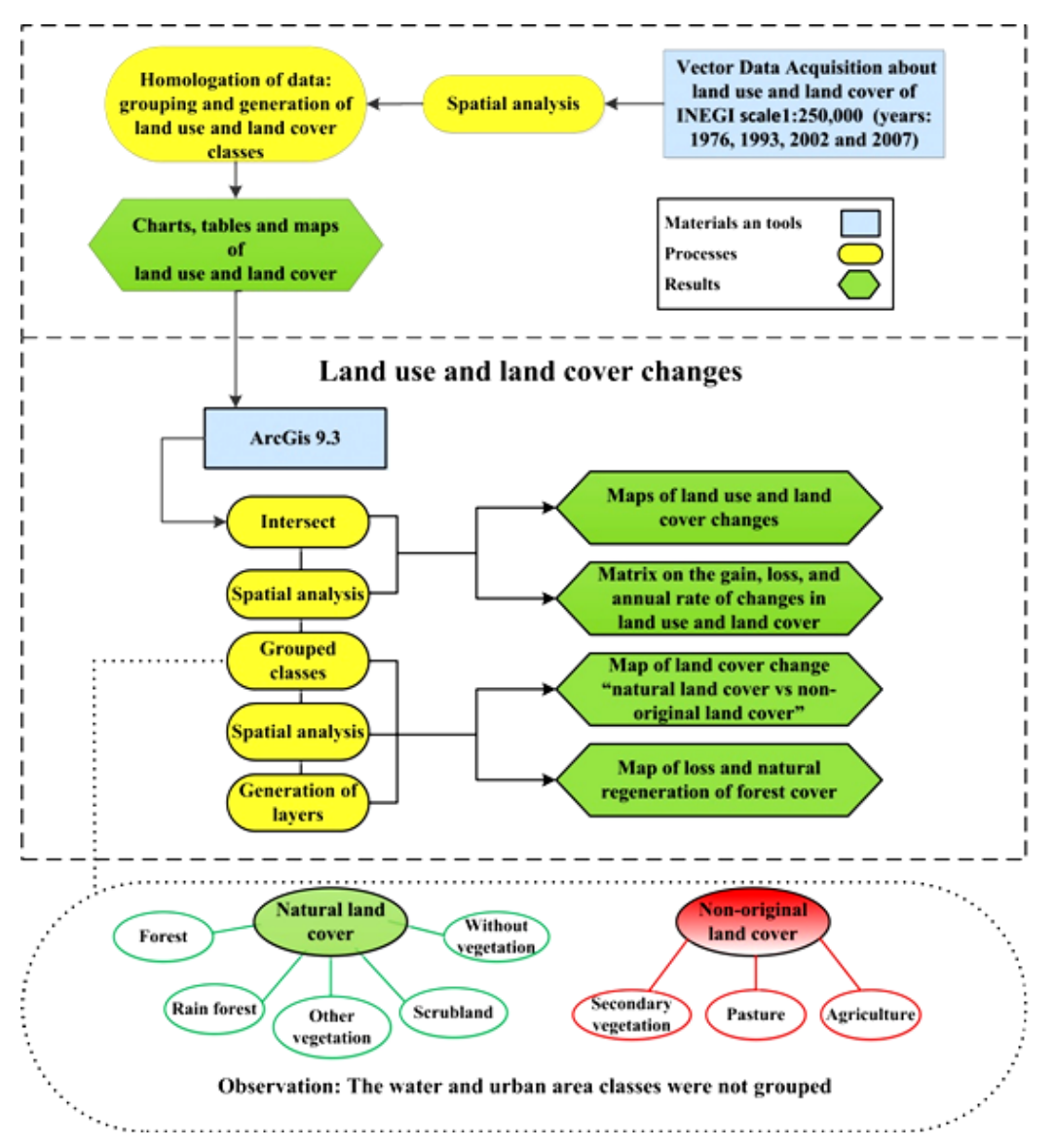

Figure 2.

Flowchart of the stages developed in the analysis of land cover and land use change. 
cover change for the different classes (Table 1).

Finally, to estimate the areas that were subject to the natural regeneration of vegetation, those covers were quantified and mapped which had reached a primary forest stratum. To identify restoration areas were recognized forest areas changed to other land uses (1976-2007) and which had a restoration potential.

\section{Results and Discussion}

\section{Land Use and Land Cover}

The dynamics of land use and land cover in the Huasteca re- gion can be reconstructed for a timeframe of 31 years (Table 2) (Figure 3), based on the analysis of the obtained information.

Table 2 indicates that the biggest areas that were mapped and quantified correspond to agriculture and pasture, representing approximately $60 \%$ of the surface of the Huasteca region in the year 2007. It can be observed that the share of agricultural land has increased by $50 \%$ over the past 31 years. This shows that agricultural modernization and industrialization, the increase of livestock, and the demand for wood and woodderived products have an important stake in the considerable increase of land cover types that were induced by humans (Aguilar-Robledo, 2001).

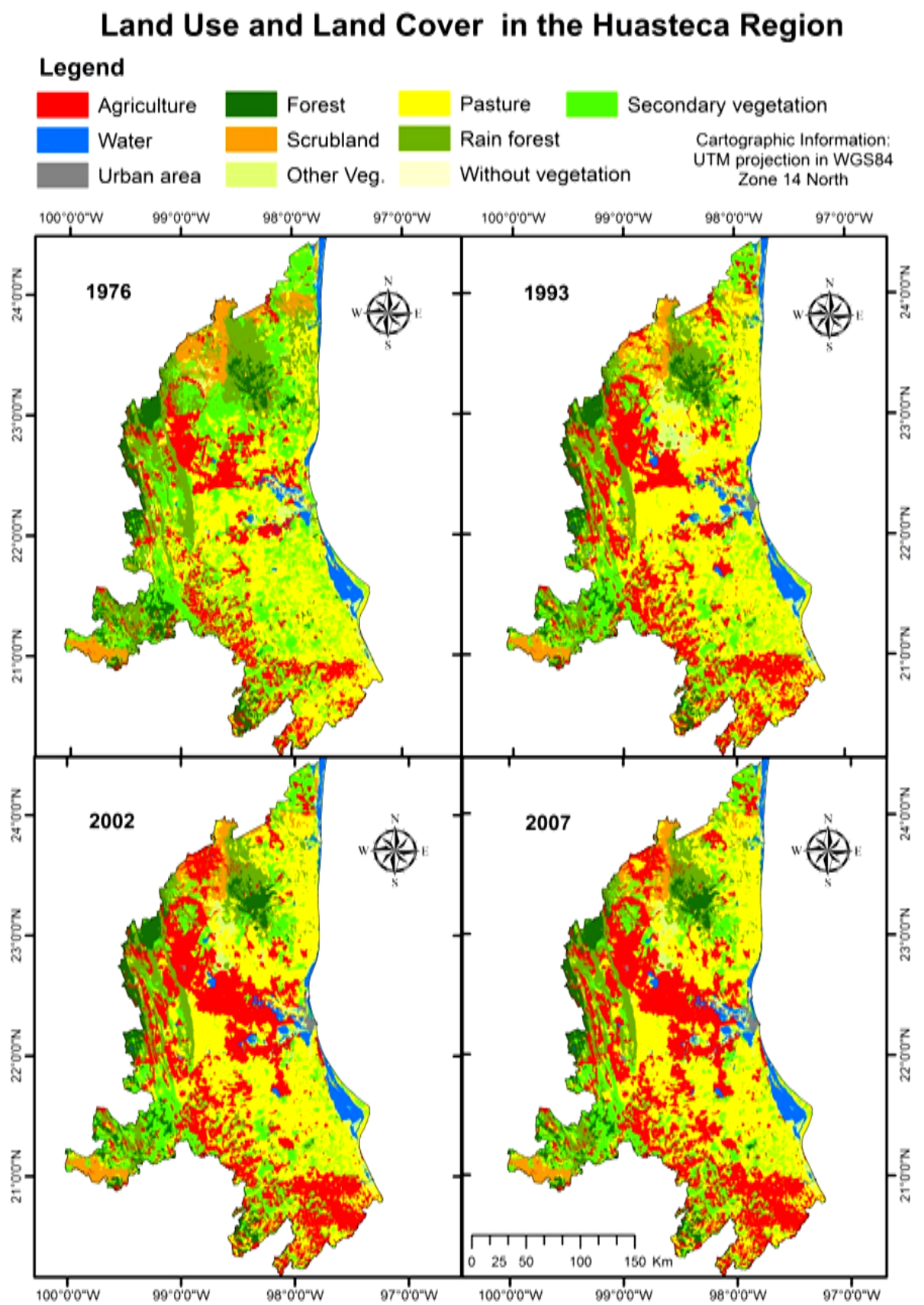

Figure 3.

Land use and land cover in the Huasteca region (1976-2007). 
Table 1.

Cross-tabulation matrix for two maps from different dates.

\begin{tabular}{|c|c|c|c|c|c|c|c|c|}
\hline \multicolumn{9}{|c|}{ Time 2} \\
\hline Time 1 & 1 & 2 & 3 & 4 & 5 & 6 & 7 & 8 \\
\hline 1 & & Class 1 & Class 2 & ......... & Class $n$ & Total $T_{1}$ & $\operatorname{Loss}\left(L_{i j}\right)$ & Lossrate \\
\hline 2 & Class 1 & $P_{11}$ & $P_{12}$ & $\ldots \ldots \ldots$. & $P_{1 n}$ & $P_{1+}$ & $P_{1+}-P_{11}$ & $\%$ \\
\hline 3 & Class 2 & $P_{21}$ & $P_{22}$ & $\ldots \ldots \ldots$ & $P_{2 n}$ & $P_{2+}$ & $P_{2+}-P_{22}$ & $\%$ \\
\hline 4 & $\ldots \ldots \ldots$ & $\ldots \ldots \ldots$. & ........ & ........ & $\ldots \ldots \ldots$ & $\ldots \ldots \ldots$ & ……......... & $\%$ \\
\hline 5 & Class $n$ & $P_{n 1}$ & $P_{n 2}$ & ......... & $P_{n n}$ & $P_{n^{+}}$ & $P_{n^{+}}-P_{n n}$ & $\%$ \\
\hline 6 & Total $T_{2}$ & $P_{+1}$ & $P_{+2}$ & $\ldots \ldots \ldots$. & $P_{+n}$ & $P$ & & \\
\hline 7 & $\operatorname{Gain}\left(G_{i j}\right)$ & $P_{+1}-P_{11}$ & $P_{+2}-P_{22}$ & ......... & $P_{+n}-P_{n n}$ & & & \\
\hline
\end{tabular}

Source: Pontius et al., 2004 y FAO, 1996.

Table 2.

Sistematization of the areas according to class and year of classification.

\begin{tabular}{|c|c|c|c|c|c|c|c|c|}
\hline & 1976 & 1993 & 2002 & 2007 & 1976 & 1993 & 2002 & 2007 \\
\hline Classes & $\mathbf{k m}^{2}$ & $\mathbf{k m}^{2}$ & $\mathbf{k m}^{2}$ & $\mathbf{k m}^{2}$ & $\%$ & $\%$ & $\%$ & $\%$ \\
\hline Agriculture & 10206.76 & 14265.25 & 17701.80 & 18477.82 & 15.54 & 21.72 & 26.95 & 28.13 \\
\hline Water & 1911.56 & 2245.01 & 2242.83 & 2313.97 & 2.91 & 3.42 & 3.42 & 3.52 \\
\hline Urban area & 51.39 & 351.03 & 438.64 & 508.87 & 0.08 & 0.53 & 0.67 & 0.77 \\
\hline Forest & 4165.14 & 3598.73 & 3553.75 & 3548.43 & 6.34 & 5.48 & 5.41 & 5.40 \\
\hline Scrubland & 3064.50 & 2360.94 & 2177.06 & 2148.29 & 4.67 & 3.59 & 3.31 & 3.27 \\
\hline Other vegetation & 1726.66 & 2385.14 & 1686.28 & 1713.34 & 2.63 & 3.63 & 2.57 & 2.61 \\
\hline Pasture & 18067.40 & 22169.03 & 20882.93 & 20148.85 & 27.51 & 33.76 & 31.80 & 30.68 \\
\hline Rain forest & 9410.23 & 6665.79 & 6088.87 & 6102.92 & 14.33 & 10.15 & 9.27 & 9.29 \\
\hline Without vegetation & 25.51 & 72.36 & 71.24 & 71.90 & 0.04 & 0.11 & 0.11 & 0.11 \\
\hline
\end{tabular}

Obtained data demonstrates that for the studied years, forest cover (rain forest, forest and scrubland) in particular has been reduced, as affirmed by Quinteros (2012).

\section{Land Use and Land Cover Changes}

The most reliable statistical data for the analysis of land use and land cover changes use for the years of study correspond to data on the vegetal cover, while the least reliable data refers to water and urban areas. Data of land use and land cover shows slight imprecision with regard to the transition, which has also occurred in other analysis on land cover and land use change in Mexico (Velázquez et al., 2002). Nonetheless, reasonable evidence of LUCC was found when crossing $t_{1}-t_{2}, t_{2}-t_{3}$ and $t_{3}-t_{4}$, while also taking account of the particular dynamics of the ecosystems that had been analyzed.

Of the changes that occurred between $t_{1}-t_{2}$, the increase in agriculture $(1.99 \%)$ as well as a change in the deforestation rate of rain forests $-2.01 \%$ must be noted, the latter being higher than the general national deforestation rate for Mexico, $(-0.25$ and $-1.02 \%)$ according to Velázquez et al., 2002, and (-0.76\%) according to Mas et al., (2009). In comparison, only the state of Veracruz has a higher deforestation rate $(-2.2 \%)$, and the deforestation rate is generally lower in all other states of the Mexican Republic (Céspedes-Flores \& Moreno-Sánchez, 2010). Furthermore, urban areas increased by $500 \%$ over the same time period, while areas without vegetation, despite the fact that their growth rate is merely $6.33 \%$, have increased by $56.03 \mathrm{~km}^{2}$ (Table 3).

Between 1993 and $2002\left(\mathrm{t}_{2}-\mathrm{t}_{3}\right)$, most classes of land cover and land use suffered from losses, except for agriculture, water and urban areas. The greatest loss of forest cover was registered for the categories "other types of vegetation" $(-3.78 \%)$ and "rain forest" $(-1.41 \%)$, again at a higher rate than the rate calculated by Velázquez et al., (2002). For other types of land cover and land use the loss was less amounting to $0.9 \%$ (Table 4).

Between 2002 and $2007\left(t_{3}-t_{4}\right)$, the loss and gain rates of land use and land cover were much smaller than for the previous periods. A gain could be observed for the category rain forest and other vegetation with $249.55 \mathrm{~km}^{2}$ and $236.55 \mathrm{~km}^{2}$ respectively. Also, urban areas increased annually by $3.01 \%$, and agriculture by $0.86 \%$, as reported by Algara (2009), which had an important impact on the transformation of ecosystems (Table 5).

\section{General Changes in Land Use and Land Cover}

By crossing data from four years (1976, 1993, 2002 and 2007) it can be observed that the pressure of human-induced activities on natural land cover (forest, rain forest, other vegetation, scrubland and no vegetation) has increased exponentially, which translates into an increase of non-original cover (secondary vegetation, pasture and agriculture). Despite this, in 2007 
Table 3.

Cross-tabulation matrix or change matrix between $\mathrm{t}_{1}$ and $\mathrm{t}_{2}$ (data in $\mathrm{km}^{2}$ ).

\begin{tabular}{|c|c|c|c|c|c|c|c|c|c|c|c|c|c|}
\hline \multicolumn{14}{|c|}{1993} \\
\hline 1976 & $\begin{array}{l}\text { 总 } \\
\text { 芯 } \\
\text { 总 }\end{array}$ & $\begin{array}{l}\frac{\vec{w}}{\pi} \\
\frac{\pi}{3}\end{array}$ & 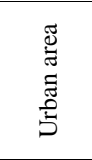 & 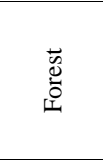 & 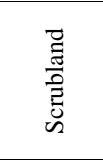 & 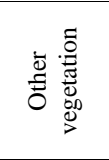 & 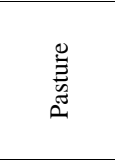 & 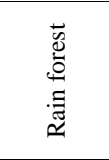 & 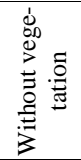 & 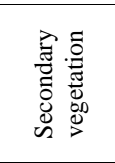 & 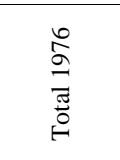 &  & 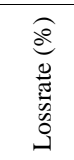 \\
\hline Agriculture & 7901.13 & 98.60 & 103.12 & 94.48 & 30.49 & 362.92 & 761.07 & 136.26 & 3.65 & 715.04 & 10206.76 & 2305.63 & 1.99 \\
\hline Water & 37.85 & 1602.29 & 0.00 & 0.14 & 6.30 & 154.86 & 70.37 & 4.82 & 22.76 & 12.17 & 1911.57 & 309.28 & 0.97 \\
\hline Urban area & 0.58 & 1.28 & 48.33 & 0 & 0 & 0.31 & 0.87 & 0 & 0.01 & 0 & 51.39 & 3.06 & 11.82 \\
\hline Forest & 168.69 & 0.71 & 1.23 & 2968.13 & 27.54 & 9.57 & 166.44 & 138.25 & 0 & 684.60 & 4165.14 & 1197.01 & -0.86 \\
\hline Scrubland & 136.14 & 7.37 & 1.71 & 5.43 & 2077.65 & 13.28 & 634.57 & 49.94 & 0 & 138.40 & 3064.50 & 986.85 & -1.52 \\
\hline Other vegetation & 166.78 & 259.82 & 8.02 & 5.11 & 24.93 & 843.03 & 311.93 & 41.69 & 14.41 & 50.94 & 1726.67 & 883.63 & 1.92 \\
\hline Pasture & 2238.15 & 149.35 & 106.30 & 58.48 & 18.91 & 236.94 & 13259.08 & 155.47 & 5.11 & 1839.61 & 18067.40 & 4808.32 & 1.21 \\
\hline Rain forest & 684.77 & 25.30 & 9.30 & 187.12 & 62.40 & 50.51 & 1774.82 & 5874.45 & 2.02 & 739.55 & 9410.23 & 3535.78 & -2.01 \\
\hline Without vegetation & 0 & 2.61 & 0.22 & 0 & 0 & 3.49 & 0.68 & 0 & 16.34 & 2.16 & 25.51 & 9.17 & 6.33 \\
\hline Secondary vegetation & 2931.15 & 105.61 & 64.87 & 279.85 & 112.72 & 710.22 & 5189.22 & 264.90 & 8.07 & 7380.08 & 17046.69 & 9666.61 & -2.26 \\
\hline Total 1993 & 14265.25 & 2252.95 & 343.09 & 3598.73 & 2360.94 & 2385.14 & 22169.03 & 6665.79 & 72.37 & 11562.56 & & & \\
\hline Gain & 6364.12 & 650.66 & 294.76 & 630.60 & 283.28 & 1542.11 & 8909.96 & 791.34 & 56.03 & 4182.48 & & & \\
\hline
\end{tabular}

Table 4.

Cross-tabulation matrix or change matrix between $\mathrm{t}_{2}$ and $\mathrm{t}_{3}$ (data in $\mathrm{km}^{2}$ ).

\begin{tabular}{|c|c|c|c|c|c|c|c|c|c|c|c|c|c|}
\hline \multicolumn{14}{|c|}{2002} \\
\hline 1993 & 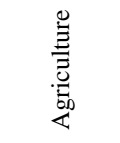 & 离 & 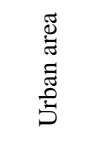 &  & $\begin{array}{l}\text { च्च } \\
\frac{\pi}{0} \\
\bar{Z} \\
w\end{array}$ & 离 & 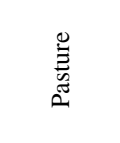 & 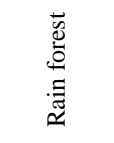 & 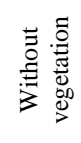 &  & 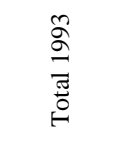 &  & 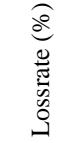 \\
\hline Agriculture & 12579.24 & 49.44 & 45.32 & 67.39 & 41.76 & 81.43 & 807.98 & 154.83 & 0.03 & 437.85 & 14265.25 & 1686.01 & 2.43 \\
\hline Water & 60.94 & 2071.78 & 0.00 & 0.81 & 2.85 & 77.61 & 0.00 & 0.00 & 10.26 & 20.78 & 2245.01 & 173.24 & 0.45 \\
\hline Urban area & 43.30 & 6.81 & 295.17 & 0.00 & 0.42 & 2.36 & 0.00 & 0.00 & 0.00 & 2.96 & 351.03 & 55.85 & 2.85 \\
\hline Forest & 70.40 & 0.80 & 1.32 & 3088.95 & 5.91 & 2.75 & 114.60 & 77.81 & 0.00 & 236.19 & 3598.73 & 509.78 & -0.14 \\
\hline Scrubland & 140.56 & 8.35 & 0.51 & 4.35 & 1959.26 & 24.84 & 136.88 & 53.92 & 0.00 & 32.27 & 2360.94 & 401.68 & -0.90 \\
\hline Other vegetation & 132.94 & 74.12 & 9.72 & 1.42 & 16.85 & 1374.88 & 555.19 & 66.76 & 2.80 & 150.46 & 2385.14 & 1010.27 & -3.78 \\
\hline Pasture & 3547.92 & 94.99 & 60.44 & 68.45 & 84.87 & 81.43 & 17436.16 & 0.00 & 0.96 & 793.81 & 22169.03 & 4732.87 & -0.60 \\
\hline Rain forest & 232.08 & 9.66 & 13.17 & 199.76 & 35.59 & 14.17 & 420.05 & 5382.64 & 1.15 & 357.51 & 6665.79 & 1283.15 & -1.41 \\
\hline $\begin{array}{c}\text { Without } \\
\text { vegetation }\end{array}$ & 0.00 & 3.43 & 2.05 & 0.00 & 0.00 & 4.72 & 2.43 & 0.00 & 54.40 & 5.34 & 72.36 & 17.96 & -0.12 \\
\hline $\begin{array}{l}\text { Secondary } \\
\text { vegetation }\end{array}$ & 894.40 & 17.94 & 24.27 & 122.08 & 29.56 & 22.11 & 1523.69 & 131.24 & 2.02 & 8795.27 & 11562.57 & 2767.31 & -0.72 \\
\hline Total 2002 & 17701.79 & 2337.30 & 451.98 & 3553.21 & 2177.06 & 1686.29 & 20996.98 & 5867.19 & 71.61 & 10832.44 & & & \\
\hline Gain & 5122.55 & 265.53 & 156.80 & 464.26 & 217.80 & 311.41 & 3560.82 & 484.55 & 17.21 & 2037.17 & & & \\
\hline
\end{tabular}

the Huasteca region still conserved approximately 10602.59 $\mathrm{km}^{2}$ of original land cover representing $16.4 \%$ of the surface (Table 6).
Furthermore, the development of total changes in land cover and land use amount to $17.84 \%$, or $11718.82 \mathrm{~km}^{2}$ of the Huasteca region (Table 7), as shown in detail in (Table 8). 
Table 5.

Cross-tabulation matrix or change matrix between $\mathrm{t}_{3}$ and $\mathrm{t}_{4}$ (data in $\mathrm{km}^{2}$ ).

\begin{tabular}{|c|c|c|c|c|c|c|c|c|c|c|c|c|c|}
\hline \multicolumn{14}{|c|}{2007} \\
\hline 2002 & $\frac{\mathscr{\Xi}}{\stackrel{\Xi}{Z}}$ & 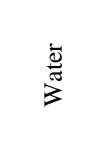 & 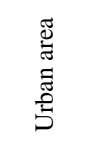 & $\begin{array}{l}\overrightarrow{\tilde{d}} \\
\stackrel{0}{0} \\
\text { I. }\end{array}$ & 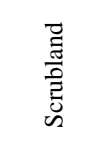 & 莺 & 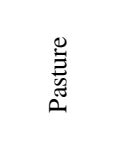 & 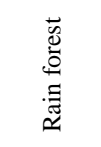 & 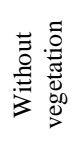 & 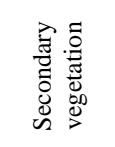 & 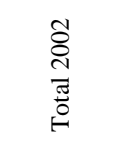 & బે & 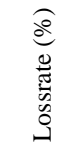 \\
\hline Agriculture & 16829.65 & 19.07 & 32.79 & 9.47 & 0.85 & 24.18 & 351.08 & 77.46 & 0.55 & 356.71 & 17701.80 & 872.15 & 0.86 \\
\hline Urban area & 0.70 & 0.12 & 437.41 & 0.02 & 0.00 & 0.00 & 0.36 & 0.00 & 0.00 & 0.03 & 438.64 & 1.23 & 3.01 \\
\hline Forest & 14.91 & 0.00 & 0.00 & 3496.50 & 0.57 & 3.43 & 19.01 & 4.08 & 0.00 & 15.24 & 3553.75 & 57.25 & -0.03 \\
\hline Scrubland & 12.60 & 0.11 & 0.45 & 0.53 & 2128.25 & 0.82 & 30.71 & 0.03 & 0.00 & 3.56 & 2177.06 & 48.82 & -0.27 \\
\hline Other vegetation & 77.09 & 71.71 & 3.02 & 0.00 & 0.11 & 1476.80 & 25.51 & 3.83 & 0.68 & 27.54 & 1686.29 & 209.49 & 0.32 \\
\hline Rain forest & 64.79 & 0.91 & 0.00 & 22.36 & 0.00 & 0.06 & 58.45 & 5853.37 & 0.61 & 88.34 & 6088.87 & 235.51 & 0.05 \\
\hline Without vegetation & 0.11 & 0.00 & 0.00 & 0.00 & 0.00 & 2.80 & 0.07 & 0.46 & 67.16 & 0.64 & 71.24 & 4.08 & 0.18 \\
\hline Secondary vegetation & 719.22 & 0.51 & 8.39 & 5.82 & 0.83 & 15.12 & 351.16 & 106.68 & 1.28 & 9623.43 & 10832.44 & 1209.00 & -0.36 \\
\hline Total 2007 & 18477.93 & 2313.87 & 508.87 & 3548.43 & 2148.29 & 1713.35 & 20148.85 & 6102.92 & 71.90 & 10641.45 & & & \\
\hline Gain & 1648.28 & 129.47 & 71.46 & 51.93 & 20.04 & 236.55 & 842.16 & 249.55 & 4.74 & 1018.02 & & & \\
\hline
\end{tabular}

Table 6.

Evolution of the status and changes in all the grouped and maintained covers in the years 1976, 1993,2002 and 2007.

\begin{tabular}{|c|c|c|}
\hline Covers that maintained the same state & $\mathbf{k m}^{2}$ & $\%$ \\
\hline Natural cover maintained until 2007 & 10602.59 & 16.14 \\
\hline Urban area maintained until 2007 & 46.97 & 0.07 \\
\hline Water maintained until 2007 & 1478.60 & 2.25 \\
\hline Cover changes & 11718.82 & 17.84 \\
\hline Error & 670.29 & 1.02 \\
\hline
\end{tabular}

Table 7.

General evolution of land cover change for the Huasteca region from 1976 until 2007.

\begin{tabular}{|c|c|c|}
\hline Development of changes in land cover and land use & $\mathbf{k m}^{2}$ & $\%$ \\
\hline Cover maintained until 2007 & $53,286.74$ & 81.14 \\
\hline Error & 670.29 & 1.02 \\
\hline
\end{tabular}

Table 8 indicates that the main changes occurred with regard to natural covers which transformed into non-original covers, mostly in the period of time between 1976 and 1993 with $4911.88 \mathrm{~km}^{2}$, followed by $1892.5 \mathrm{~km}^{2}$ for the period of time between 2002 and 2007, and finally $1029.78 \mathrm{~km}^{2}$ for the period of time between 1993 and 2002.

In spite of this loss of natural cover, $1318.68 \mathrm{~km}^{2}$ were recovered between 1976 and 1993, $974.18 \mathrm{~km}^{2}$ between 1993 and 2002 as well as $468.43 \mathrm{~km}^{2}$ between 2002 and 2007. The total change in land cover (17.84\%) for the Huasteca region, equaling $11,718.82 \mathrm{~km}^{2}$, can be observed in $100 \%$ (Figure 4).
Natural Regeneration and Potential Areas for Restoration

Areas of land cover and land use that regenerated naturally to forest cover between the years 1976 and 2007 are approximately $721.25 \mathrm{~km}^{2}$ of forest area and $1210.82 \mathrm{~km}^{2}$ of rain forests, without taking into account changes between other forest covers. The greatest natural regeneration took place between 1976 and 1993 for both forest types. At the same time, the greatest loss of these ecosystems falls also into this timeframe (1021.66 $\mathrm{km}^{2}$ of forest area and $3235.75 \mathrm{~km}^{2}$ of rain forest). In 
Table 8.

Changes in land use and land cover of reclassified classes in the Huasteca region, years 1976, 1993, 2002 and 2007.

\begin{tabular}{|c|c|c|}
\hline Cambios en las Coberturas & $\mathbf{k m}^{2}$ & $\%$ \\
\hline Water that changed to non-original land cover between 1976-1993 & 79.32 & 0.12 \\
\hline Water that changed to natural land cover between 1976-1993 & 92.66 & 0.14 \\
\hline Water that changed to natural land cover between 1993-2002 & 83.09 & 0.13 \\
\hline Water bodies mantained between 1976 and $2007^{*}$ & 1478.60 & 2.25 \\
\hline Urban area maintained between 1976 and $2007^{*}$ & 46.97 & 0.07 \\
\hline Non-original land cover that changed to water between 1976-1993 & 243.15 & 0.37 \\
\hline Non-original land cover that changed to urban area between 1976-1993 & 210.42 & 0.32 \\
\hline Non-original land cover that changed to natural land cover 1976-1993 & 1318.68 & 2.01 \\
\hline Non-original land cover that changed to natural land cover 1993-2002 & 974.18 & 1.48 \\
\hline Non-original land cover that changed to natural land cover 2002-2007 & 468.43 & 0.71 \\
\hline Natural land cover that changed to water between 1976-1993 & 211.39 & 0.32 \\
\hline Natural land cover that changed to water between 1993-2002 & 90.38 & 0.14 \\
\hline Natural land cover that changed to water between 2002-2007 & 73.02 & 0.11 \\
\hline Natural land cover that changed to urban area between 1976-1993 & 14.44 & 0.02 \\
\hline Natural land cover that changed to urban area between 1993-2002 & 25.51 & 0.04 \\
\hline Natural land cover that changed to non-original land cover 1976-1993 & 4911.88 & 7.48 \\
\hline Natural land cover that changed to non-original land cover 1993-2002 & 1029.78 & 1.57 \\
\hline Natural land cover that changed to non-original land cover 2002-2007 & 1892.50 & 2.88 \\
\hline Non-original land cover maintained between $1976-2007^{*}$ & 41158.59 & 62.67 \\
\hline Natural land cover maintained between $1976-2007^{*}$ & 10602.59 & 16.14 \\
\hline Error or other changes of land use and land cover** & 670.29 & 1.02 \\
\hline Total & 65675.85 & 100 \\
\hline
\end{tabular}

"Covers without a change in land use or land cover from 1976 until the year 2007. ${ }^{* *}$ The margin of error refers to possible inconsistencies with regard to classification; inconsistent changes in land use and land cover take into account the individual dynamics of ecosystems and problems of overlap.

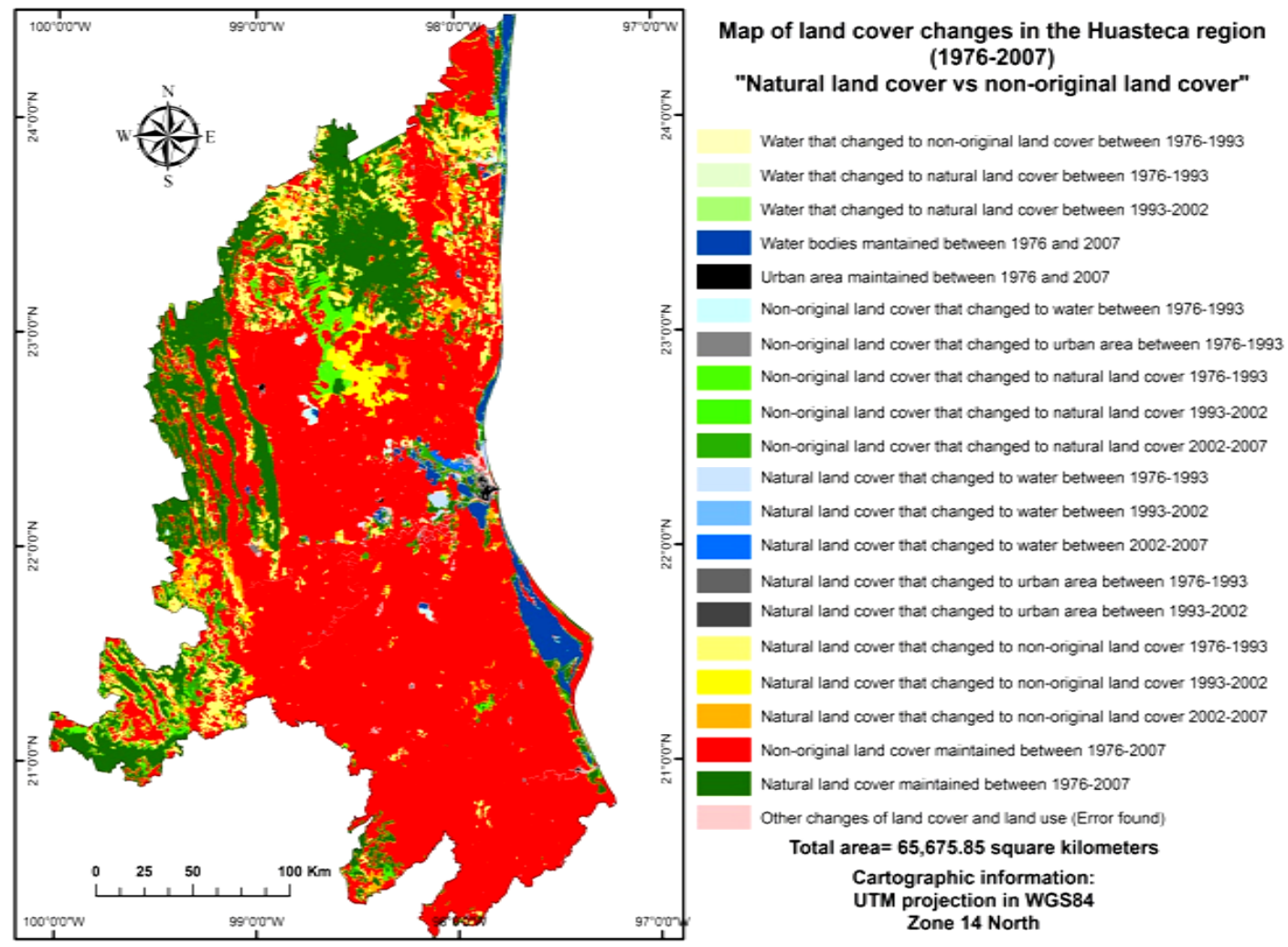

Figure 4.

Land covers dynamics of the grouped classes for the Huasteca región, for the periods 1976-1993, 1993-2002 and 2002-2007. 
total, $1310.82 \mathrm{~km}^{2}$ of forest and $4482.47 \mathrm{~km}^{2}$ of rain forest were lost or deforested between 1976 and 2007, without accounting for the change towards other types of forest cover (Figure 5). Hence, the areas that had been deforested or put to other use are an indicator of the main potential areas which should be restored in the region in order to restore the forest cover (Figure 5).

\section{Conclusion}

It can be concluded that the thematic maps illustrating changes in land cover and land use for the period of study (1976-2007), and that were created based on GIS methods and techniques, are adequate for the evaluation and the analysis of the changes that have occurred in the Huasteca region.

In the analysis of land use and land cover changes, more reliable statistical results correspond to vegetation cover, while the least reliable appear to be the water and urban area classes, the same categories that presents small inaccuracies in the transitions of changes.

Analysis carried out based on a cross-tabulation matrix demonstrated that agriculture and pasture in particular have modified the biophysical landscape of the Huasteca over the period of time from 1976 until 1993.



Figure 5.

Deforestation and natural regeneration of forest cover in the Huasteca region, 1976-2007. 
Deforestation rates for rain forests, forests, scrublands and other types of vegetation were also higher than the national deforestation rates reported for México by other authors, even though for the period of time between 2002 and 2007 a backward trend could be observed.

The analysis which measured the land cover change (natural land cover and non-original land cover), we envisioned that non-original coverage increased by $7834.16 \mathrm{~km}^{2}$, and natural land cover only recovered $2761.29 \mathrm{~km}^{2}$ in the same period of 31 years. Furthermore, this method showed that $62.67 \%$ of the surface of the Huasteca region had been modified by human activities before the year 1976, and from 1976 until 2007 changes affected $17.84 \%$ of the studied area.

It was also demonstrated that the greatest loss of forest cover in the Huasteca between 1976 and 2007 amounted to 1310.82 $\mathrm{km}^{2}$ for forests and $4482.47 \mathrm{~km}^{2}$ for rain forests, while the natural regeneration of non-forest covers to forest covers made up $721.25 \mathrm{~km}^{2}$ for forests and $1210.82 \mathrm{~km}^{2}$ for rain forests.

Between the years 1976 and 2007 an area of approximately $1932.07 \mathrm{~km}^{2}$ regenerated naturally to forest cover (forests and rainforests), and $5739.29 \mathrm{~km}^{2}$ were identified as potential areas for forest restoration.

\section{REFERENCES}

Aguilar-Robledo, M. (2001). Ganadería, tenencia de la tierra, e impacto ambiental en la Huasteca Potosina: los años de la Colonia. In L. Hernández (Ed.), Historia ambiental de la ganadería en México (pp. 9-24). Xalapa: Instituto de Ecología-Institut de Recherche pour le Développement.

Algara, M. (2009). Propuesta metodológica para medir el impacto del fenómeno de la sequía en la Huasteca Potosina y propuesta general de manejo. Tesis para doctorado en ciencias ambientales. San Luis Potosí: Universidad Autónoma de San Luis Potosí.

Bassols, B. Á. (1993). Geografía económica de México. Trillas: Teoría, Fenómenos Generales, Análisis Regional.

Berberoglu, S., \& Akin, A. (2009). Assessing different remote sensing techniques to detect land use/cover changes in the eastern Mediterranean. International Journal of Applied Earth Observation and Geoinformation, 11, 46-53. http://dx.doi.org/10.1016/j.jag.2008.06.002

Castillo-Santiago, M. A., Hellier, A., Tipper, R., \& De Jong, B. H. J. (2007). Carbon emissions from land use change: An analysis of causal factors in Chiapas, Mexico. Mitigation and Adaptation Strategies for Global Change, 12, 1213-1235. http://dx.doi.org/10.1007/s11027-006-9060-7

Céspedes-Flores, S., \& Moreno-Sánchez, E. (2010). Estimación del valor de pérdida de recurso forestal y su relación con la deforestación en las entidades federativas de México. Investigación Ambiental, 2, 5-13.

CONABIO (2012). Distribución de la población en México por municipio, 2010, escala: 1:250000. Comisión Nacional Para el Conocimiento y Uso de la Biodiversidad. México D.F.: Datos estadísticos del 2010, del Instituto Nacional de Estadística y Geografía (INEGI).

Dirzo, R., \& García, M. (1992). Rates of deforestation in Los Tuxtlas, a neotropical area in southeast Mexico. ConservationBiology, 6, 84-90.

FAO/FRA (2010). Evaluación de los recursos forestales mundiales 2010 (p. 98). Roma: Informe Nacional México. Organización de las Naciones Unidas Para la Agricultura y la Alimentación. http://dx.doi.org/10.1046/j.1523-1739.1992.610084.x

FAO (1996). Forest resources assessment 1990. Survey of tropical forest cover and study of change processes. Roma: FAO.

Green, E. P., Mumby, P. J., Edwards, A. J., \& Clark, C. D. (1996). A review of remote sensing for the assessment and management of tropical coastal resources. Coastal Management, 24, 1-40. http://dx.doi.org/10.1080/08920759609362279

Klemas, V. (2001). Remote sensing of landscape-level coastal environmental indicators. Environmental Management, 27, 47-57. http://dx.doi.org/10.1007/s002670010133

Lambin, E. F., \& Geist, H. J. (2007). Causes of land use and land cover change. Washington DC: Encyclopedia of Earth, Environmental Information Coalition, National Council for Science and the Environment.

http://www.eoearth.org/article/Land-use_and_land-cover_change

Lambin, E. F., Geist, H. J., \& Lepers, E. (2003). Dynamics of land use and land cover change in tropical regions. Annual Reviews of Environment and Resources, 28, 205-231.

López Blanco, J. (2005). Sistemas de información geográfica en estudios de geomorfología ambiental y recursos naturales. Ciudad de México: Universidad Nacional Autónoma de México.

Mas, J.-F., Velázquez, A., \& Couturier, S. (2009). La evaluación de los cambios de cobertura/uso del suelo en la República Mexicana. Investigación Ambiental, 1, 23-39.

Márquez-Linares, M. A., Treviño, E. J., \& Jurado, E. (2005). Reemplazo de áreas arboladas por chaparrales y comunidades herbáceas en el período 1970-2000 en una Microcuenca de Durango, México. Investigaciones Geográficas, 58, 54-65.

Miranda-Aragón, L., Treviño-Garza, E. J., Jiménez-Pérez, J., AguirreCalderón, O. A., González-Tagle, M. A., Pompa-García, M., \& AguirreSalado, C. A. (2013). Tasas de deforestación en San Luis Potosí, México (1993-2007). Revista Chapingo Serie Ciencias Forestales y del Ambiente, 2, 201-215. http://dx.doi.org/10.5154/r.rchscfa.2011.06.044

Oliva, V. E., López, J., Caballero, J., \& Martínez, M. A. (2010). Patrones espaciales de cambio de cobertura y uso del suelo em el área cafetalera de la sierra norte de Puebla. Investigaciones Geográficas, 72, 23-38.

Pacheco, P., Ormachea, E., Cronkleton, P., Albornoz, M., \& Paye, L. (2009). Trayectorias y tendencias de la economía extractiva en el norte amazónico de Bolivia. La Paz: CIFOR-CEDLA.

Peralta-Rivero, C., Contreras, C., Galindo, M. G., Torrico, J. C., \& Vos, V. A. (2013). Cambios de Uso del Suelo, y Proyectos Forestales MDL y REDD en Riberalta, Amazonía Boliviana. CienciAgro, 4, 403-420.

Pontius, R. G., Shusas, E., \& McEachern, M. (2004). Detecting important categorical land changes while accounting for persistence. Agriculture, Ecosystems and Environment, 101, 251-268. http://dx.doi.org/10.1016/j.agee.2003.09.008

Quinteros, J. (2012). Estudio ambiental y social comparativo del bosque húmedo en base al cambio de uso de suelo entre la Huasteca Potosina, México y la Mata Atlántica, rio de janeiro, Brasil. Tesis de maestría en ciencias ambientales. San Luis Potosí: Universidad Autónoma de San Luis Potosí.

Ramankutty, N., Graumlinch, L., Achard, F., Alves, D., Chhabra, A., DeFries, R. S., Foley, J. A., Geist, H., Houghton, R. A., Goldewijk, K., Lambin, E. F., Millington, A., Rasmussen, K., Reid, R. S., \& Turner, B. L. (2006). Global land-cover change: Recentprogress, remainingchallenges. In E. F. Lambin, \& H. Geist (Eds.), Land-use and land-change. Local processes and global impacts (pp. 9-40). Berlin: Springer-Verlag.

Ricker, M. (2010). La cobertura forestal y la problemática de ladeforestaciónen México (pp. 1-6). Mexico City: Instituto de Biología. Universidad Nacional Autónoma de México. file://J//MARTIN\%20FILES/MARTIN'S\%20PDFS/PÁGINA\%20A GOSTO\%202010/webCoverForDefor.htm

Rosete-Vergés, F., Pérez-Damián, J. L., \& Bocco, G. (2009). Contribución al análisis de cambios de uso del suelo y vegetación (19782000) en la peninsula de Baja California, México. Investigación Ambiental, Ciencia y Política Pública, 1, 70-82.

Vitousek, P., Ehrlich, P., Ehrlich, A., \& Matson, P. (1986). Human appropriation of the products of photosynthesis. BioScience, 36, 368-374. http://dx.doi.org/10.2307/1310258

Velázquez, A., Mas, J. F., Díaz, J. R., Mayorga, R., Alcántara, P. C., Castro, R., Fernández, T., Bocco, G., Ezcurra, E., \& Palacio, J. L. (2002). Patrones y tasas de cambio de uso de suelo en México. Gaceta Ecológica, 62, 21-37.

Weckmüller, R., Slovinscky, N. C., \& Vicens, R. (2011). O uso das geotecnologias como subsídio à análise da evolução do uso e cobertura do solo: Caso do Corredor Ecológico do Muriqui/RJ. Rio de

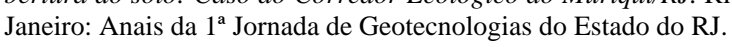


Appendix 1. Classification and Reclassification of Land Use and Land Cover Classes Employed in the Analysis of Land Use and Land Cover Changes for the Huasteca Region

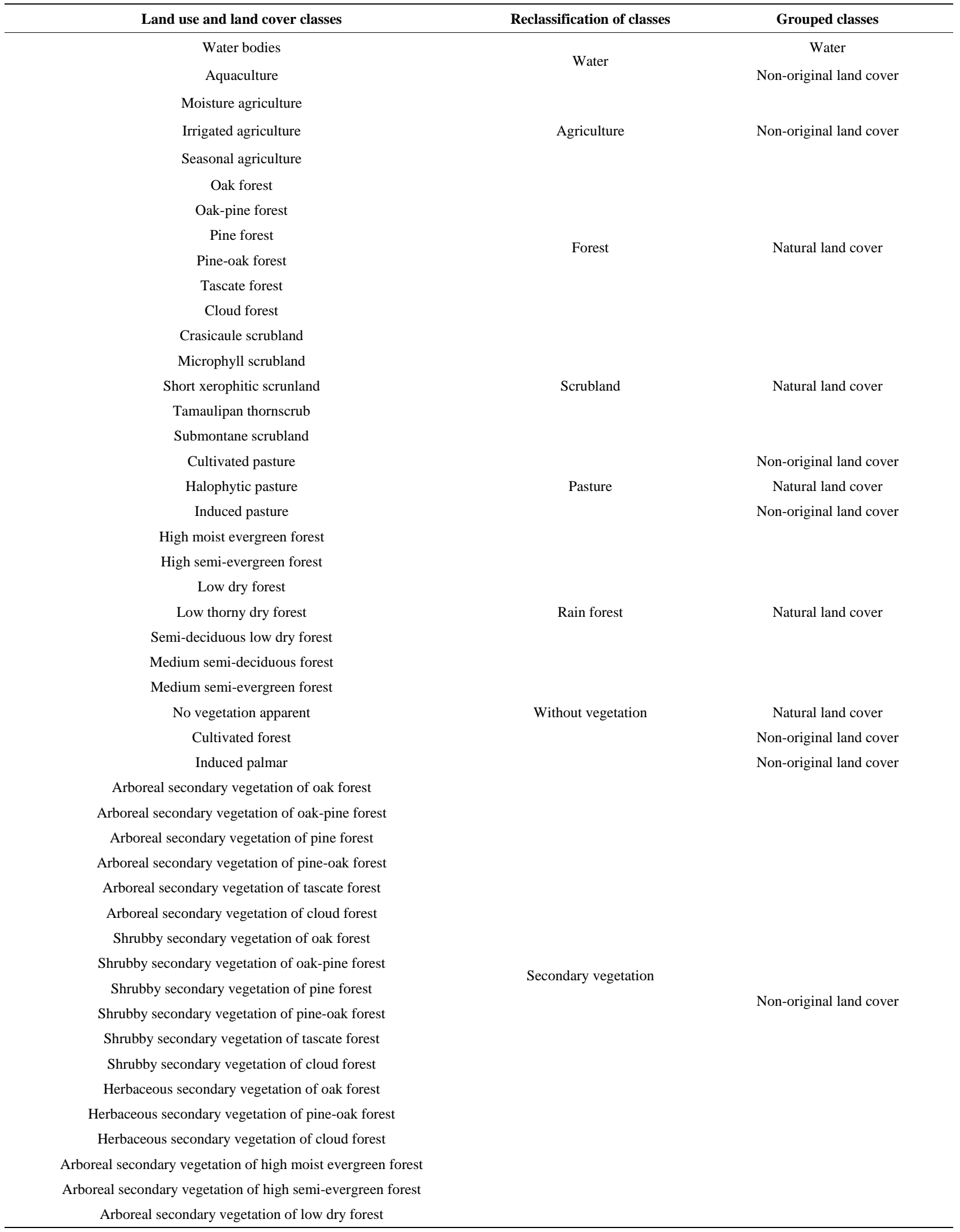




\section{Continued}

Arboreal secondary vegetation of low thorny dry forest Arboreal secondary vegetation of low thorny semi-evergreen forest Arboreal secondary vegetation of medium semi-evergreen forest Arboreal secondary vegetation of low thorny forest

Arboreal secondary vegetation of medium semi-deciduous forest

Shrubby secondary vegetation of high evergreen forest

Shrubby secondary vegetation of high semi-evergreen forest

Shrubby secondary vegetation of low dry forest

Shrubby secondary vegetation of low thorny dry forest

Shrubby secondary vegetation of low semi-deciduous forest

Shrubby secondary vegetation of medium semi-deciduous forest

Shrubby secondary vegetation of medium semi-evergreen forest

Shrubby secondary vegetation of low thorny forest

Shrubby secondary vegetation of low semi-evergreen forest

Herbaceous secondary vegetation of high evergreen forest

Herbaceous secondary vegetation of low thorny forest

Herbaceous secondary vegetation of high semi-evergreen forest

Herbaceous secondary vegetation of low dry forest

Herbaceous secondary vegetation of medium semi-evergreen forest

Shrubby secondary vegetation of microphyll scrubland

Shrubby secondary vegetation of crasicaule scrubland

Shrubby secondary vegetation of conifer scrubland

Shrubby secondary vegetation of submontane scrubland

Shrubby secondary vegetation of tamaulipan thornscrub

Shrubby secondary vegetation of chaparral

Shrubby secondary vegetation of mezquital

Herbaceous secondary vegetation of submontane scrubland

\section{Chaparral \\ Mezquital \\ Palmar}

Costal dunes vegetation

Natural land cover

Gallery vegetation

Mesquite forest

Native palmar

Mangroves

Gallery rain forest

Gallery forest

Floodable

Natural land cover

Halophilous vegetation

Reed beds

Urban zone

Human settlements 